\title{
Phosphorus studies in pigs
}

\section{Assessing phosphorus availability for pigs and rats}

\author{
BY P. P. KETAREN*, E. S. BATTERHAM A AD E. BELINDA DETTMANN\$ \\ NSW Agriculture, Wollongbar Agricultural Institute, Wollongbar, NSW 2477, Australia \\ AND D. J. FARRELL \\ Department of Biochemistry, Microbiology and Nutrition, University of New England, Armidale, \\ NSW 2351, Australia
}

(Received 4 December 1991 - Accepted 7 September 1992)

\begin{abstract}
Experiments were conducted with pigs and rats to determine the availability of $P$ in feeds. Initially, the availability of $P$ in a soya-bean meal and field peas (Pisum sativum cultivar Early Dun) was assessed using a slope-ratio assay for grower pigs. Three different levels of either monosodium phosphate (MSP), soya-bean meal or field peas were added to a basal sucrose-soya-bean meal diet $(2.5 \mathrm{~g} / \mathrm{kg} \mathrm{P})$ to give three levels of $P(3.0,3.5$ and $4 \mathrm{~g} / \mathrm{kg})$ for each source. The diets were offered for $35 \mathrm{~d}$ at three times maintenance energy requirements to female pigs initially weighing $20 \mathrm{~kg}$ live weight. Several bone variables and the ash and $P$ concentration and retention levels in the empty body were used as criteria of availability. The responses to MSP were linear for all variables. However, responses to $P$ in the test proteins, particularly soya-bean meal, were mostly non-linear, except for ash and $P$ concentrations and retentions in the empty body. The estimates of $P$ availability in the soya-bean meal and in the field peas were dependent on the criteria used to assess availability. Using bone variables as the criterion, the availabilities of $P$ in soya-bean meal and field peas were approximately 0.17 and 0.38 respectively. Using ash or $P$ concentrations or retentions in the empty body as the response criterion, the availabilities of $P$ in soya-bean meal and field peas were 0.61 and 0.38 respectively. The mean retention values for $P$ from MSP, soya-bean meal and field peas were 0.74, 0.33 and 0.21 respectively. Experiments were then conducted to define the conditions necessary for a slope-ratio assay for $P$ availability with growing rats to determine if they could be used as a model to assess $P$ availability for pigs. These experiments examined level of $P$ in the diet, the effect of $\mathrm{Ca}: \mathrm{P}$ ratio and criteria for assessing response (growth rate, feed intake, feed conversion ratio, bone ash and bone bending moment). The results indicated that a suitable range of dietary $P$ for a slope-ratio assay in rats was $1.8-3.5 \mathrm{~g} / \mathrm{kg}$, with $\mathrm{Ca}: P$ ratio of between 1.3 and 6.2, and that ash content or bone bending moment of the femur bone were suitable criteria of response. However, using bone bending moment as the criterion of response, the availability of $P$ in soyabean meal was 0.81 , which was considerably higher than the estimate with pigs. Overall the results indicated that the estimates of the availability of $P$ in feeds for pigs were dependent on the criteria used to assess availability and that the value for rats led to an overestimate of the value for pigs.
\end{abstract}

Phosphorus availability: Assessment criteria: Rats: Pigs

$P$ in plant material is much less available than $P$ in animal materials or inorganic phosphate as it is found organically in the form of phytate-P, which is not readily available for pigs (Cromwell, 1980). However, as the availability of $\mathrm{P}$ in most feeds has not been fully

\footnotetext{
* Present address: Balai Penelitian Ternak, Departemen Pertanian, PO Box 123, Bogor, Indonesia.

$\dagger$ For reprints.

$\ddagger$ Present address: Australian National Parks and Wildlife Service, Canberra, ACT 2600, Australia.
} 
established, most of the recommendations for P are based on total P. A slope-ratio assay procedure has been developed by Cromwell (1980) to determine the availability of $P$ in feed ingredients for pigs. Using this assay the estimate of $P$ availability in some feed ingredients for pigs varies from 0 to 1 (National Research Council, 1988; Cromwell, 1989). These values were based on changes in bone bending moment (a measure of bone strength).

Previous work (Ketaren et al. 1993) indicated that in addition to bone bending moment, ash concentration in the radius/ulna bone and $\mathrm{P}$ and ash concentration in the empty body appeared to be suitable criteria for assessing the response to changes in dietary $P$ levels. In particular, these responses for total $P$ retention may have the advantage that they account for all this $\mathrm{P}$ compared with responses with the bone variables which only account for a portion of the $P$ utilization in the body.

Slope-ratio assays with pigs are time-consuming and expensive and the use of rats to predict $P$ availability would be quicker and considerably less expensive. However, to use a slope-ratio assay with growing rats it is first necessary to define an experimental procedure. In particular, level of dietary $\mathrm{P}$, effect of other minerals and suitable response criteria need to be defined. With regard to P concentration, the National Research Council's (1972) recommendations for minimum $\mathrm{Ca}$ and $\mathrm{P}$ contents are approximately 5 and $4 \mathrm{~g} / \mathrm{kg}$ respectively in the diet for growth and bone development of rats. $\mathrm{A} \mathrm{Ca}: \mathrm{P}$ ratio between 1.0 and 2.0 was also recommended. It was reported that increasing dietary $\mathrm{P}$ from 1.5 to $4.5 \mathrm{~g} / \mathrm{kg}$ in rats increased $\mathrm{Ca}, \mathrm{P}$, ash and bone bending moment of the femur bone linearly (Moore et al. 1984). Other highly calcified tissues such as teeth may also be used as a criterion of response, although they may not necessarily respond to dietary $\mathrm{Ca}$ and $\mathrm{P}$ levels in the same way as other bones (Oser, 1965).

It is also uncertain whether variation in the $\mathrm{Ca}: \mathrm{P}$ ratio would affect the measurement of $\mathrm{P}$ availability. In the assay developed by Cromwell (1980), the feeding of an optimal Ca level $(6 \mathrm{~g} / \mathrm{kg})$, in association with suboptimal $P$ levels, resulted in a wide variation in $\mathrm{Ca}: \mathrm{P}$ ratio from 1.6 to 3 . Some reports in the literature indicate that bone bending moment of growing pigs was affected not only by the $\mathrm{P}$ level but also by the $\mathrm{Ca}: \mathrm{P}$ ratio in the diets (e.g. Koch \& Mahan, 1985). Therefore, in developing a slope-ratio assay with rats it is important to determine if variation in the $\mathrm{Ca}: \mathrm{P}$ ratio in the $\mathrm{P}$-deficient diets affects $\mathrm{P}$ availability.

The aims of the present study were (1) to determine the availability of $P$ in soya-bean meal and field peas (Pisum sativum cultivar Early Dun) for growing pigs, (2) to determine whether ash or total $P$ retention in the empty body is a better measure of response than bone bending moment in availability assays, (3) to determine the retention of $P$ from monosodium phosphate (MSP), soya-bean meal and field peas by pigs and to compare these values with the estimates of availability based on bone variables, (4) to develop a suitable procedure for a slope-ratio assay with rats to measure availability of $P$ in feed sources and (5) to determine the availability of $\mathrm{P}$ in soya-bean meal for growing rats and compare this value with that for the pig.

\section{EXPERIMENTA L}

\section{Expt 1. Availability of phosphorus in soya-bean meal and field peas for pigs}

In the assay developed by Cromwell (1980), pigs of approximately $15 \mathrm{~kg}$ live weight were offered a soya-bean meal-D-glucose-based diet containing $2.0 \mathrm{~g} \mathrm{P} / \mathrm{kg}$ originating from the soya-bean meal. Then graded levels of MSP were added to the basal diet to obtain three different levels of $\mathrm{P}(2 \cdot 6,3 \cdot 2$ and $3 \cdot 8 \mathrm{~g} / \mathrm{kg})$. Similarly, three levels of test ingredient were incorporated into the basal diet to supply the same levels of $\mathrm{P}$ as contributed by the MSP. These diets were offered to the pigs over a $24-42 \mathrm{~d}$ period, then the pigs were killed. Bone 
bending moment (bone breaking strength) of metacarpals, metatarsals and femur were taken as the criterion of responses and the regression of bone-bending moment $v$. $\mathbf{P}$ concentration in the diet determined. The slope of bone bending moment of pigs receiving the test ingredient divided by the slope of bone bending moment of pigs receiving the MSP is the estimate of $\mathrm{P}$ availability for the test ingredient. The estimate of availability is a mean of the bone bending moment responses from the three different bones.

The general principles of the slope-ratio assay developed by Cromwell (1980) were followed in the present work except for a number of modifications. The pigs weighed $20 \mathrm{~kg}$ at the commencement of the experiment, the range in total $\mathbf{P}$ concentration was $2.5-4.0 \mathrm{~g} / \mathrm{kg}$, the diets were fed restrictively rather than ad lib., and a greater number of variables were used to assess response.

Diets. Two batches of soya-bean meal were used in the diets. The first batch, containing $(\mathrm{g} / \mathrm{kg})$ crude protein $(\mathrm{N} \times 6.25) 441$, crude fibre 46 , diethyl ether extract 12 , ash $58, \mathrm{Ca} 2.6$, $\mathrm{P} 7 \cdot 1$ ( $880 \mathrm{~g}$ dry matter $/ \mathrm{kg}$, air-dry basis), was used in the basal diet. The second batch, containing $(\mathrm{g} / \mathrm{kg}$ ) Ca $2 \cdot 8$, P 6.7 ( $890 \mathrm{~g}$ dry matter $/ \mathrm{kg}$, air-dry basis), was used for the test soya-bean meal. This batch had also been used previously in the determination of the a vailable-P requirements for grower pigs (Ketaren et al. 1993). Concentrations of protein, amino acids and other nutrients in the test soya-bean meal were described by Ketaren et al. (1993).

The field peas contained ( $\mathrm{g} / \mathrm{kg}$ ) Ca $0 \cdot 9, \mathrm{P} 4.4$ (900 g dry matter $/ \mathrm{kg}$, air-dry basis) and were coarsely crushed through a hammer mill. The field peas contained $(\mathrm{g} / \mathrm{kg})$ crude protein 173 , crude fibre 37 , diethyl ether extract 19 , ash 28 and the digestible energy content $(13.8 \mathrm{MJ} / \mathrm{kg}$ ) was taken from Davies (1984).

The diets were formulated in a similar manner to that of Ketaren et al. (1993). Sugar (sucrose) and soya-bean meal were chosen for these studies. Sucrose is a P-free source of energy while soya-bean meal is a uniform source of protein which is also low in available $P$. In addition, the availability of $P$ in soya-bean meal has been estimated to be 0.25 (National Research Council, 1988). The basal diet was formulated to $15.5 \mathrm{MJ}$ digestible energy $/ \mathrm{kg}$ and $0.62 \mathrm{~g}$ available lysine/MJ digestible energy (Standing Committee on Agriculture, 1987; Table 1). Additional amino acids were added to maintain the balance of amino acids, relative to lysine, as recommended by the Agricultural Research Council (1981).

MSP, containing $222 \mathrm{~g} \mathrm{P} / \mathrm{kg}$, was added to the basal diet to obtain three levels of total $P(3 \cdot 0,3.5$ and $4.0 \mathrm{~g} / \mathrm{kg})$. Similarly, three levels of either soya-bean meal or field peas were incorporated into the basal diet to supply the same levels of total $\mathbf{P}$ as those contributed by the MSP. Thus, there were ten diets for this assay. Soya-bean oil was added at the expense of sucrose to obtain the same calculated level of digestible energy in all diets (15.5 MJ/kg).

Animals and procedures. The ten diets were arranged in a randomized block design. The pigs were blocked according to 7 -week weight, sex and position in the experimental facilities. There were six blocks, each containing ten females of the Large White breed. The pigs were housed individually in cement slatted floored pens in an insulated building and the minimum temperature was maintained at $22^{\circ}$. Water was supplied by nipple drinkers.

Dietary treatments were introduced when the pigs reached $20 \mathrm{~kg}$ live weight. The diets were offered at three times maintenance energy requirement. The pigs were fed eight times daily at $3 \mathrm{~h}$ intervals using an automatic frequent feeder. The diets were offered air-dry. Rations were adjusted after the weekly weighing of the pigs.

The pigs were slaughtered after $35 \mathrm{~d}$ on the experimental diet using an electric stunner. The blood was collected and the viscera washed to remove undigested material. The blood and washed viscera were then combined and frozen. The carcasses (with hair) were washed 
Table 1. Expt 1. Composition ( $\mathrm{g} / \mathrm{kg}$, air-dry basis) of the basal diet

\begin{tabular}{lr}
\hline \hline & 353.0 \\
Components & 618.4 \\
Soya-bean meal & 4.2 \\
Sucrose & 1.9 \\
Soya-bean oil & 1.8 \\
DL-Methionine & 1.8 \\
L-Valine & 1.6 \\
L-Lysine hydrochloride & 5.0 \\
Threonine & 13.3 \\
Vitamins and minerals* & \\
Limestone & 156.0 \\
Composition $\dagger$ & 15.5 \\
Crude protein $(\mathrm{N} \times 6.25)$ & 10.8 \\
Digestible energy $(\mathrm{MJ} / \mathrm{kg})$ & 6.0 \\
Lysine & 2.5 \\
Ca & 2.4 \\
Total P & \\
Ca:total P ratio & \\
\hline
\end{tabular}

\footnotetext{
* Contributed the following (mg/kg diet): Fe 60, $\mathrm{Zn} \mathrm{100,} \mathrm{Mn} \mathrm{30,} \mathrm{Cu} \mathrm{5,} \mathrm{I} \mathrm{2,} \mathrm{Se} \mathrm{0.15,} \mathrm{NaCl} 2 \cdot 8 \mathrm{~g}$, retinol equivalent $960 \mu \mathrm{g}$, cholecalciferol $12 \mu \mathrm{g}, \alpha$-tocopherol 20 , thiamine 1.5 , riboflavin 3, nicotinic acid 14, pantothenic acid 10 , pyridoxine $2 \cdot 5$, cyanocobalamin $15 \mu \mathrm{g}$, pteroylmonoglutamic acid 2 , choline 552 , ascorbic acid 10 , biotin $0 \cdot 1$.

$\uparrow$ Soya-bean meal and limestone contained $(\mathrm{g} / \mathrm{kg})$ : Ca $2 \cdot 6$ and 382 , total P $7 \cdot 1$ and 0 .
}

clean with water, split longitudinally down the middle of the vertebrae and the left-hand side stored at $-15^{\circ}$, then ground, mixed, sampled and freeze-dried before chemical analyses. The blood and viscera were processed in a similar manner. Four different bones (radius/ulna, femur, metacarpal ${ }_{4}$ and metatarsal ${ }_{4}$ ) were collected from the right-hand side of the carcass and stored at $-15^{\circ}$. The bones were then thawed to room temperature, autoclaved at $120^{\circ}$ for $6 \mathrm{~min}$ and cleaned of all flesh using a scalpel. These bones were chosen as Ketaren et al. (1993) reported that the radius/ulna and femur bones were more responsive than other bones to the changes in dietary $\mathbf{P}$ concentration for grower pigs, while the metacarpal ${ }_{4}$, metatarsal ${ }_{4}$ and femur bones were used as response criteria by Cromwell $(1980,1989)$.

In order to determine $\mathrm{P}$ retention, six female pigs were slaughtered at the commencement of the experiment ( $20 \mathrm{~kg}$ live weight) and $\mathrm{P}$ concentrations of the blood plus washed viscera and whole carcass were determined as described for pigs slaughtered after $35 \mathrm{~d}$ on the experimental diets.

Pig response was assessed in terms of feed intake, daily live-weight gain, feed conversion ratio (FCR; feed intake: live-weight gain), empty body-weight : final live weight, gain/d and FCR on an empty body-weight basis, depth of backfat measured at the $P_{2}$ position (fat plus skin using a Danish optical intrascope $65 \mathrm{~mm}$ from the dorsal mid-line at the level of the posterior edge of the head of the last rib), concentration and total weight of ash in the bones, bone strength as measured by bone bending moment, and the concentration and retention of ash and $\mathrm{P}$ in the empty body. After the bone bending determinations the bones were cut into approximately $25 \mathrm{~mm}$ pieces, oven-dried at $105^{\circ}$ and ground in a laboratory mill $(3 \mathrm{~mm}$ screen) for chemical analyses.

Here the following factors were used: 0.92 to convert initial live weight to estimated empty body-weight and $4.32 \mathrm{~g} \mathrm{P} / \mathrm{kg}$ empty body-weight basis for the pigs at the commencement of the experiment. These factors were determined on the six pigs killed at the commencement of the experiment. 
Analytical methods and determination of bone bending moment. The analytical methods and determination of bone bending moment were as described by Ketaren et al. (1993).

Statistical analyses. The effect of treatments on growth, bone and empty-body variables was determined by a linear regression analysis with regressions determined for variable $v$. $\mathrm{P}$ concentration in the diets or $\mathrm{P}$ intake. The estimate of $\mathrm{P}$ availability was expressed as slope of the response to the soya-bean meal or field pea diets:slope of the response to the MSP diets. In many cases, particularly with soya-bean meal, the responses were non-linear. Rather than delete these analyses, the estimates of $P$ availability were still calculated for comparative purposes.

\section{Expt 2. Effect of calcium: phosphorus ratio in diets for rats}

The aim of this experiment was to develop a suitable assay procedure for a slope-ratio assay to determine $\mathrm{P}$ availability. In particular to examine the effect of a variable or constant $\mathrm{Ca}: \mathrm{P}$ ratio in diets containing increasing levels of $\mathrm{P}$ from 2.6 to $6.2 \mathrm{~g} / \mathrm{kg}$ using growth performance, bone mineralization in the lower jaws and bone bending moment of the femur bone as criteria of response.

Diets. Nine experimental diets containing low and high levels of total $\mathrm{P}(2 \cdot 6,3 \cdot 5,4 \cdot 4,5 \cdot 3$ and $6.2 \mathrm{~g} / \mathrm{kg})$ with either variable $(0.9,1 \cdot 1,1 \cdot 3,1.6$ and $2 \cdot 1)$ or constant $(1 \cdot 3) \mathrm{Ca}: \mathrm{P}$ ratios were formulated by substituting the required amount of $\mathrm{CaCO}_{3}$ and $\mathrm{MSP}$ for sucrose in soya-bean meal-sucrose-based diets (Table 2). The diets were formulated to contain adequate amino acids and other minerals and vitamins according to the recommendations of the National Research Council (1972). In the basal diet, soya-bean meal was the only source of dietary P.

Animals and procedures. Three male and three female albino rats, approximately $28 \mathrm{~d}$ old, were used in each treatment. They were allocated to the treatments based on litter and sex. The rats were individually caged in a room where the temperature and relative humidity were maintained at $21 \pm 1^{\circ}$ and $50 \pm 5 \%$ respectively. Lighting was provided for $12 \mathrm{~h}$ daily; feed and water were supplied $a d l i b$. in a self feeder or drinker respectively. Feed intake and live-weight gain were recorded weekly.

At the completion of a $21 \mathrm{~d}$ test the rats were killed with chloroform. The right femur bones were collected for bone ash and bone bending moment determinations. The left femur bones and lower jaws (plus teeth) were collected for $\mathrm{Ca}$ and $\mathrm{P}$ determinations.

Analytical methods and determination of bone bending moment. Bone bending moment of the femur bone was determined using an Instron testing unit (model 4302). Bones were placed on two supports $10 \mathrm{~mm}$ apart and force applied perpendicular to the midshaft at a constant speed of $5 \mathrm{~mm} / \mathrm{min}$ until it reached the maximum force needed to break the bones. Bone bending moment was then calculated using the equation established by Crenshaw et al. (1981).

Ash content of the samples, previously oven dried at $105^{\circ}$ for $16 \mathrm{~h}$ and then fat extracted using acetone in a Soxhlet apparatus, was determined by ashing at $650^{\circ}$ for $16 \mathrm{~h}$. For $\mathrm{Ca}$ and $\mathrm{P}$ determinations, samples were wet ashed first with $\mathrm{HNO}_{3}$ then followed by $\mathrm{HClO}_{4}$ (Johnson \& Ulrich, 1959). Ca was then determined with an atomic absorption spectrophotometer (SP 1900 Pye Unicam) at $422.4 \mathrm{~nm}$ using a stoichiometric $\mathrm{C}_{2} \mathrm{H}_{2}-\mathrm{N}_{2} \mathrm{O}$ flame. P was determined colorimetrically (John, 1970) at $827 \mathrm{~nm}$ in a Shimadzu UV-240 spectrophotometer.

Statistical analyses. The effect of treatments on growth and bone variables was determined by analysis of variance. Treatment effects were partitioned to test the linear and quadratic effects of dietary $\mathrm{P}$ levels, with variable or constant $\mathrm{Ca}: \mathrm{P}$ ratio, and to test the difference between the linear regressions of variable and constant $\mathrm{Ca}: \mathbf{P}$ ratio. 
Table 2. Expts 2, 3, and 4. Composition ( $\mathrm{g} / \mathrm{kg}$, air-dry basis) of the basal diets

\begin{tabular}{|c|c|c|c|c|}
\hline \multirow[t]{2}{*}{ Expt no.... } & \multirow[t]{2}{*}{2} & \multicolumn{2}{|c|}{3} & \multirow[t]{2}{*}{4} \\
\hline & & $\begin{array}{c}\text { For diets } \\
1 \text { and } 6\end{array}$ & $\begin{array}{l}\text { For other } \\
\text { diets }\end{array}$ & \\
\hline \multicolumn{5}{|l|}{ Components } \\
\hline Soya-bean meal* & $340 \cdot 0$ & 1260 & $251 \cdot 5$ & $300 \cdot 0$ \\
\hline Sucrose & $612 \cdot 4$ & $786 \cdot 0$ & $691 \cdot 2$ & $640 \cdot 0$ \\
\hline Soya-bean oil & $20 \cdot 0$ & $20 \cdot 0$ & $20 \cdot 0$ & $20 \cdot 0$ \\
\hline DL-Methionine & $4 \cdot 5$ & $5 \cdot 5$ & $4-9$ & $2 \cdot 6$ \\
\hline L-Glutamic acid & $10 \cdot 9$ & $29 \cdot 2$ & $18 \cdot 4$ & $18 \cdot 3$ \\
\hline L-Valine & $0 \cdot 3$ & $3 \cdot 9$ & $1 \cdot 8$ & $1 \cdot 6$ \\
\hline L-Lysine hydrochloride & - & $5 \cdot 6$ & $2 \cdot 2$ & 1.9 \\
\hline L-Tryptophan & - & $0 \cdot 8$ & $0 \cdot 1$ & - \\
\hline L-Isoleucine & - & $3 \cdot 3$ & $1 \cdot 1$ & 0.8 \\
\hline L-Arginine & - & $1 \cdot 6$ & - & - \\
\hline L-Histidine & - & $1 \cdot 3$ & - & - \\
\hline L-Leucine & - & $3 \cdot 1$ & - & - \\
\hline L-Phenylalanine & - & $3 \cdot 1$ & - & - \\
\hline L-Proline & - & $0 \cdot 8$ & - & - \\
\hline L-Threonine & - & $2 \cdot 4$ & - & - \\
\hline Vitamins and mineralst & $5 \cdot 0$ & $5 \cdot 0$ & $5 \cdot 0$ & $5 \cdot 0$ \\
\hline $\mathrm{CaCO}_{3}$ & $5 \cdot 9$ & 1.9 & $3 \cdot 7$ & $10 \cdot 0$ \\
\hline MSP & $1 \cdot 0$ & - & - & - \\
\hline \multicolumn{5}{|l|}{ Composition } \\
\hline $\mathrm{Ca}$ & $3 \cdot 4$ & $1 \cdot 2$ & $2 \cdot 4$ & $4 \cdot 8$ \\
\hline $\mathbf{P}$ & $2 \cdot 6$ & $0 \cdot 9$ & $1 \cdot 8$ & $2 \cdot 0$ \\
\hline $\mathrm{Ca}: \mathrm{P}$ ratio & $1 \cdot 3$ & $1 \cdot 3$ & $1 \cdot 3$ & $2 \cdot 4$ \\
\hline
\end{tabular}

MSP, monosodium phosphate.

* Soya-bean meal for Expts 2 and 3 contained $(\mathrm{g} / \mathrm{kg})$ : crude protein $(\mathrm{N} \times 6.25) 463$, dry matter 883, diethyl ether (b.p. $4060^{\circ}$ ) extract 14 , crude fibre 43 , ash 66 , Ca $3 \cdot 0, \mathrm{P} 7 \cdot 0$, aspartic acid $53 \cdot 2$, threonine $19 \cdot 2$, serine $25 \cdot 3$, glutamic acid $85 \cdot 9$, glycine $20 \cdot 1$, alanine $20 \cdot 2$, cystine $9 \cdot 1$, valine $16 \cdot 8$, methionine $4 \cdot 3$, isoleucine $17 \cdot 5$, leucine $35 \cdot 0$, tyrosine $16 \cdot 0$, phenylalanine 22.9 , histidine $13 \cdot 9$, lysine 26.9 , arginine 35.4 , tryptophan 6.8 . Soya-bean meal for Expt. 4 contained $(\mathrm{g} / \mathrm{kg}$ ): crude protein 456 , crude fibre 59 , diethyl ether extract 12 , ash $60, \mathrm{Ca} 2 \cdot 8, \mathrm{P} 6.7$ (air-dry basis, $890 \mathrm{~g}$ dry matter $/ \mathrm{kg}$ ).

$\dagger$ Contributed the following (mg/kg diet): Fe $60, \mathrm{Zn} \mathrm{100,} \mathrm{Mn} \mathrm{30,} \mathrm{Cu} \mathrm{5,} \mathrm{I} \mathrm{2,} \mathrm{Se} \mathrm{0.15,} \mathrm{NaCl} 2.8 \mathrm{~g}$, retinol equivalent $960 \mu \mathrm{g}$, cholecalciferol $49 \mu \mathrm{g}, \alpha$-tocopherol 35, thiamine $1 \cdot 5$, riboflavin 3 , nicotinic acid 14 , pantothenic acid 10 , pyridoxine 7 , cyanocobalamin $15 \mu \mathrm{g}$, pteroylmonoglutamic acid 2 , choline 500 , ascorbic acid 10 , biotin $0 \cdot 1$.

\section{Expt 3. Effect of calcium: phosphorus ratio in diets for rats}

The aims of this experiment were (1) to examine the effect of variable or constant $\mathrm{Ca}: \mathrm{P}$ ratio in diets containing lower levels of $P$ than those used in Expt 2 and (2) to examine the sensitivity of growth performance or bone mineralization of the femur bone as criteria for assessing the availability of $\mathbf{P}$.

Diets. Five low levels of total $\mathrm{P}(0 \cdot 9,1 \cdot 8,2 \cdot 6,3.5$ and $4 \cdot 4 \mathrm{~g} / \mathrm{kg})$ with either variable $(1 \cdot 3$, $1 \cdot 6,2 \cdot 1,3 \cdot 1$ and $6 \cdot 2)$ or constant $(1 \cdot 3) \mathrm{Ca}: \mathrm{P}$ ratios, making up ten experimental diets, were formulated using the same ingredients as in Expt 2. In order to reduce the dietary P level to $0.9 \mathrm{~g} / \mathrm{kg}$ it was necessary to reduce the level of soya-bean meal in the basal diet to $126 \mathrm{~g} / \mathrm{kg}$ (Table 2). This diet was supplemented with additional amino acids to meet approximately the recommendations of the National Research Council (1972).

Allocation of rats and other experimental procedures were as for Expt 2. 


\section{Expt 4. Availability of phosphorus in soya-bean meal for rats}

The aim of this experiment was to determine the availability of $P$ in soya-bean meal using various criteria to assess response in a slope-ratio assay.

Diets. Three levels of total $P(2 \cdot 6,3 \cdot 2$ and $3 \cdot 8 \mathrm{~g} / \mathrm{kg})$ from MSP were added to a soya-bean meal-sucrose-based diet containing $2 \cdot 0 \mathrm{~g} \mathrm{P} / \mathrm{kg}$. Similarly, three levels of soya-bean meal were incorporated into the basal diet to supply the same amounts of total $\mathrm{P}$ as contributed by MSP. These diets were formulated by substituting the required amounts of MSP and soya-bean meal for sucrose. Ca was kept constant at $4.8 \mathrm{~g} / \mathrm{kg}$ by replacing sucrose with a corresponding amount of $\mathrm{CaCO}_{3}$ in the diet. Vitamins, minerals and amino acids were supplemented to ensure the adequacy of nutrients in the diets (National Research Council, 1972) except for $\mathrm{Ca}$ and $\mathrm{P}$. The one batch of soya-bean meal was used for both the basal diets and test soya-bean meal and was the same batch as used to determine $P$ availability in Expt 1. Composition of the basal diet is presented in Table 2.

Animals and procedures. Three male and three female albino rats, approximately $28 \mathrm{~d}$ old, were used in each treatment. They were allocated to seven treatments based on litter and sex. Experimental procedures were as for Expt 2.

At the completion of a $21 \mathrm{~d}$ test the rats were killed with chloroform. Right femurs were collected for bone weight, bone dry matter, bone ash and bone bending moment determinations.

Statistical analyses. The effect of treatments on growth and bone variables was determined by linear regression analysis with regressions for variables $v$. P concentration in the diets or $\mathrm{P}$ intake. $\mathrm{P}$ availability was expressed as slope of the response to the test diets:slope of the response to the MSP diets.

\section{RESULTS}

Expt 1. Availability of phosphorus in soya-bean meal and field peas for pigs

Growth responses. The addition of MSP resulted in linear $(P<0.01)$ increases in gain $/ \mathrm{d}$ and FCR (both on an empty-body-weight basis) of the pigs (Table 3). For the test proteins, only the response in empty-body-weight gain/d was linear $(P<0.05)$ for pigs given the soyabean meal. There was no effect of treatments on feed intake or backfat thickness $(P>0.05)$. Overall, the growth responses of the pigs to the addition of field peas were lower than the additions of MSP or soya-bean meal $(P<0.01)$.

Bone responses. The addition of MSP resulted in linear $(P<0.01)$ increases in the concentration and total weight of ash in the different bones and in bone bending moment, (Table 4) whereas all responses to the soya-bean-meal diets were non-significant $(P>0.05)$. With the field-pea diets there were linear increases in the concentration of the ash in all three bones $(P<0.05, P<0.01)$, weight of ash in the radius/ulna $(P<0.05)$ and bone bending moment of the metacarpal ${ }_{4}(P<0.05)$.

Empty body responses. Ash and $\mathrm{P}$ concentration and $\mathrm{P}$ retention in the empty body increased linearly with increase in MSP, soya-bean meal and field peas $(P<0.05, P<0.01)$ (Table 5). $P$ retained: $P$ intake increased linearly with increase in MSP $(P<0.01)$ but not with the two test meals.

Slope-ratio estimates of phosphorus availability. The mean estimates of availability for $\mathrm{P}$ in soya-bean meal using the concentration or total weight of ash, and bone bending moment were $0 \cdot 19,0 \cdot 18$ and $0 \cdot 14$ respectively (Tables 6 and 7). For field peas the estimates were $0.54,0.26$ and 0.34 respectively. All the estimates for soya-bean meal and many of the field pea estimates were based on non-linear responses to increasing dietary $P$.

When availability was based on ash or $P$ concentrations or retentions in the empty body the mean estimates were $0 \cdot 61$ and 0.38 for soya-bean meal and field peas respectively. 
Table 3. Expt 1. Feed intake and growth responses of pigs given a basal diet $(B D)$, or the basal diet supplemented with three levels of monosodium phosphate (MSP), soya-bean meal (SBM) or field peas (Pisum sativum cultivar Early Dun; $F P$ ) to provide dietary phosphorus levels from 2.5 to $4 \mathrm{~g} / \mathrm{kg} \dagger$

\begin{tabular}{|c|c|c|c|c|c|c|c|c|}
\hline Diet & $\begin{array}{l}\text { P level } \\
(\mathrm{g} / \mathrm{kg})\end{array}$ & $\begin{array}{l}\text { Feed } \\
\text { intake } \\
(\mathrm{g} / \mathrm{d})\end{array}$ & $\begin{array}{c}\text { Daily } \\
\text { live-wt } \\
\text { gain } \\
(\mathrm{g} / \mathrm{d})\end{array}$ & $\begin{array}{c}\text { FCR } \\
\text { (g intake/ } \\
\text { g live-wt } \\
\text { gain) }\end{array}$ & $\begin{array}{c}\text { Empty } \\
\text { body } \\
\text { wt:live } \\
\text { wt } \\
(\mathrm{kg} / \mathrm{kg})\end{array}$ & $\begin{array}{c}\text { Empty- } \\
\text { body-wt } \\
\text { gain } \\
(\mathrm{g} / \mathrm{d})\end{array}$ & $\begin{array}{c}\text { FCR } \\
\text { (empty- } \\
\text { body-wt } \\
\text { basis) }\end{array}$ & $\begin{array}{c}\text { Backfat } \\
\left(\mathbf{P}_{2} ; \mathrm{mm}\right)\end{array}$ \\
\hline $\mathrm{BD}$ & $2 \cdot 5$ & 1181 & 510 & $2 \cdot 32$ & 0.93 & 483 & $2 \cdot 45$ & $11 \cdot 7$ \\
\hline \multirow[t]{3}{*}{ MSP } & 3.0 & 1182 & 556 & $2 \cdot 15$ & 0.92 & 510 & $2 \cdot 34$ & 11.5 \\
\hline & $3 \cdot 5$ & 1196 & 581 & $2 \cdot 07$ & 0.92 & 541 & $2 \cdot 23$ & $11 \cdot 2$ \\
\hline & $4 \cdot 0$ & 1213 & 610 & 1.99 & 0.93 & 571 & $2 \cdot 13$ & $12 \cdot 0$ \\
\hline \multirow[t]{3}{*}{ SBM } & $3 \cdot 0$ & 1201 & 544 & $2 \cdot 22$ & 0.92 & 502 & $2 \cdot 40$ & $12 \cdot 7$ \\
\hline & $3 \cdot 5$ & 1194 & 559 & $2 \cdot 16$ & 0.92 & 517 & $2 \cdot 33$ & $10 \cdot 5$ \\
\hline & $4 \cdot 0$ & 1213 & 591 & $2 \cdot 06$ & 0.91 & 538 & $2 \cdot 27$ & $11 \cdot 0$ \\
\hline \multirow[t]{3}{*}{ FP } & $3 \cdot 0$ & 1156 & 482 & $2 \cdot 44$ & 0.92 & 448 & $2 \cdot 64$ & 112 \\
\hline & $3 \cdot 5$ & 1142 & 477 & $2 \cdot 40$ & 0.92 & 435 & $2 \cdot 63$ & $11 \cdot 8$ \\
\hline & $4 \cdot 0$ & 1207 & 562 & $2 \cdot 16$ & 0.91 & 503 & $2 \cdot 41$ & $11 \cdot 8$ \\
\hline SEM (edf 44) & & 16.6 & 21.8 & 0.072 & 0.005 & $20 \cdot 2$ & 0.082 & 0.63 \\
\hline \multirow{2}{*}{\multicolumn{9}{|c|}{$\begin{array}{l}\text { Statistical significance } \\
\text { of effect of } \$ \text { : } \\
\text { Meals }\end{array}$}} \\
\hline MSP v. SBM & & NS & & NS & & & & \\
\hline MSP $v . F P$ & & $*$ & $* *$ & $* *$ & NS & $\begin{array}{l}\text { NS } \\
* *\end{array}$ & $\begin{array}{l}\text { NS } \\
* *\end{array}$ & $\begin{array}{l}\text { NS } \\
\text { NS }\end{array}$ \\
\hline SBM $v, F P$ & & $*$ & $* *$ & $* *$ & NS & $* *$ & $* *$ & NS \\
\hline \multicolumn{9}{|l|}{ Linearity } \\
\hline MSP & & NS & $* *$ & $* *$ & NS & $* *$ & $* *$ & NS \\
\hline SBM & & NS & $*$ & $*$ & $*$ & $*$ & NS & NS \\
\hline FP & & NS & NS & NS & $* *$ & NS & NS & NS \\
\hline
\end{tabular}

FCR, feed conversion ratio; edf, error degrees of freedom; NS, $P>0.05$,

$* P<0.05, * * P<0.01$.

$\dagger$ For details of diets and procedures, see Table 1 and pp. 270-273.

$\$$ There was no interaction between meals and $\mathbf{P}$ levels.

Assessing the responses against $\mathbf{P}$ intake rather than concentration of $\mathbf{P}$ in the diet had negligible effects on the estimates of availability.

\section{Expt 2. Effect of calcium: phosphorus ratio in diets for rats}

Growth responses. Feed intake of the rats was not significantly affected by $\mathrm{P}$ level or $\mathrm{Ca}: \mathrm{P}$ ratio in the diets (Table 8$)$. Both weight gain and FCR responded quadratically $(P<0 \cdot 05)$ to dietary $P$ level with variable $\mathrm{Ca}: \mathrm{P}$ ratio, with maximum response occurring with diet 3 ( $4.4 \mathrm{~g} / \mathrm{kg}$ total $\mathrm{P}$ and $1.3 \mathrm{Ca}: \mathrm{P}$ ratio). For rats fed on the diets containing the constant $\mathrm{Ca}: \mathrm{P}$ ratio, both growth rate and FCR responded linearly $(P<0.05, P<0.01)$ with the addition of $\mathrm{P}$ depressing performance. Linear regressions of both weight gain and FCR were significantly $(P<0.05, P<0.01)$ different.

Bone responses. $\mathrm{Ca}$ and $\mathrm{P}$ content of the lower jaws (plus teeth) were not significantly affected by the $\mathrm{P}$ level, regardless of the $\mathrm{Ca}: \mathrm{P}$ ratio in the diets (Table 8). Ca content of the femur bone was significantly $(P<0.05)$ linear to the increase of $\mathrm{P}$ with variable $\mathrm{Ca}: \mathrm{P}$ ratio, but not with constant $\mathrm{Ca}: \mathrm{P}$ ratio. $\mathrm{P}$ content of the femur bones increased quadratically $(P<0.01)$ with increase in $\mathrm{P}$ content, to a maximum of $4.4 \mathrm{~g} / \mathrm{kg}$ total $\mathrm{P}$ with variable $\mathrm{Ca}: \mathrm{P}$ ratio. With constant $\mathrm{Ca}: \mathrm{P}$ ratio, $\mathrm{P}$ content in the femur bones increased linearly $(P<0 \cdot 01)$ 


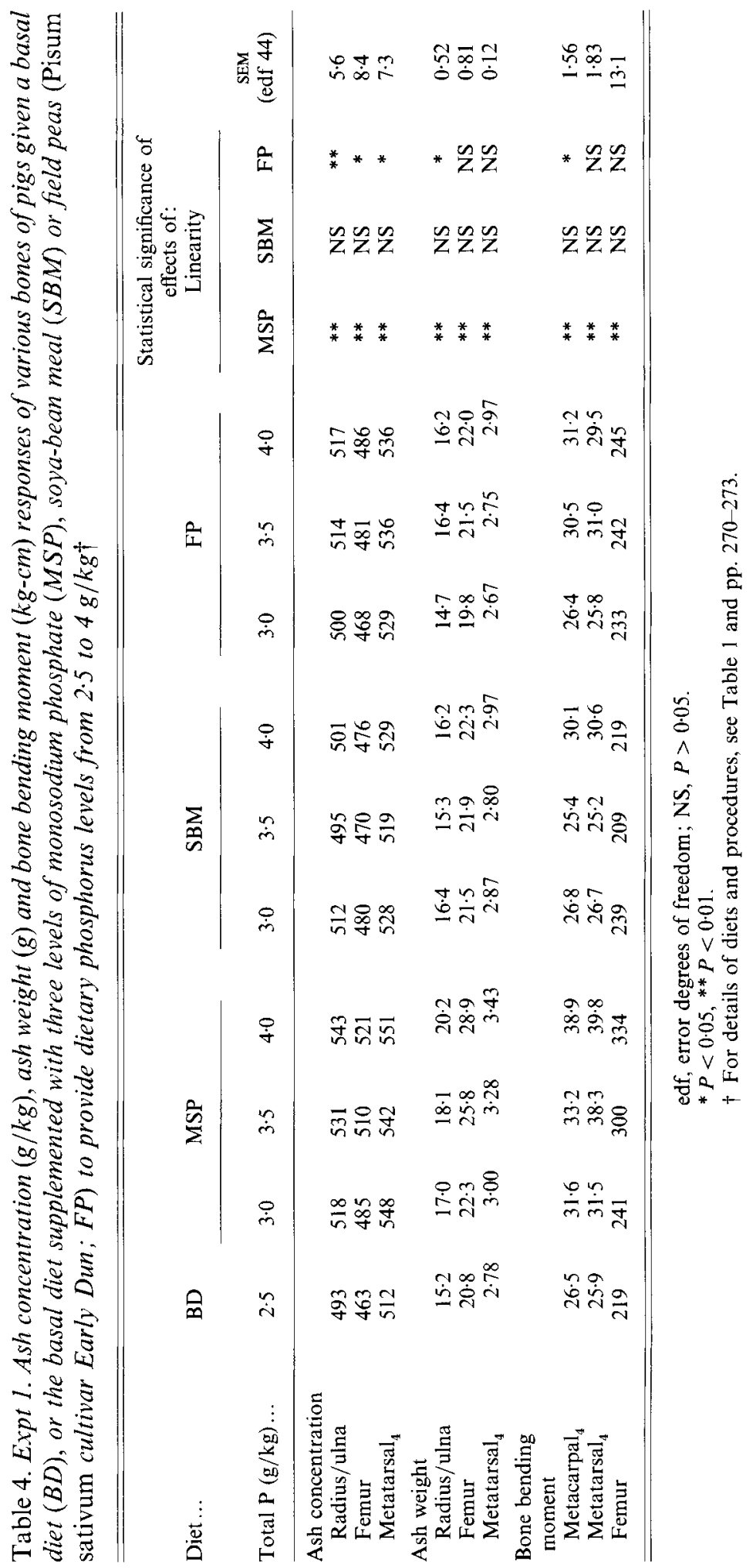




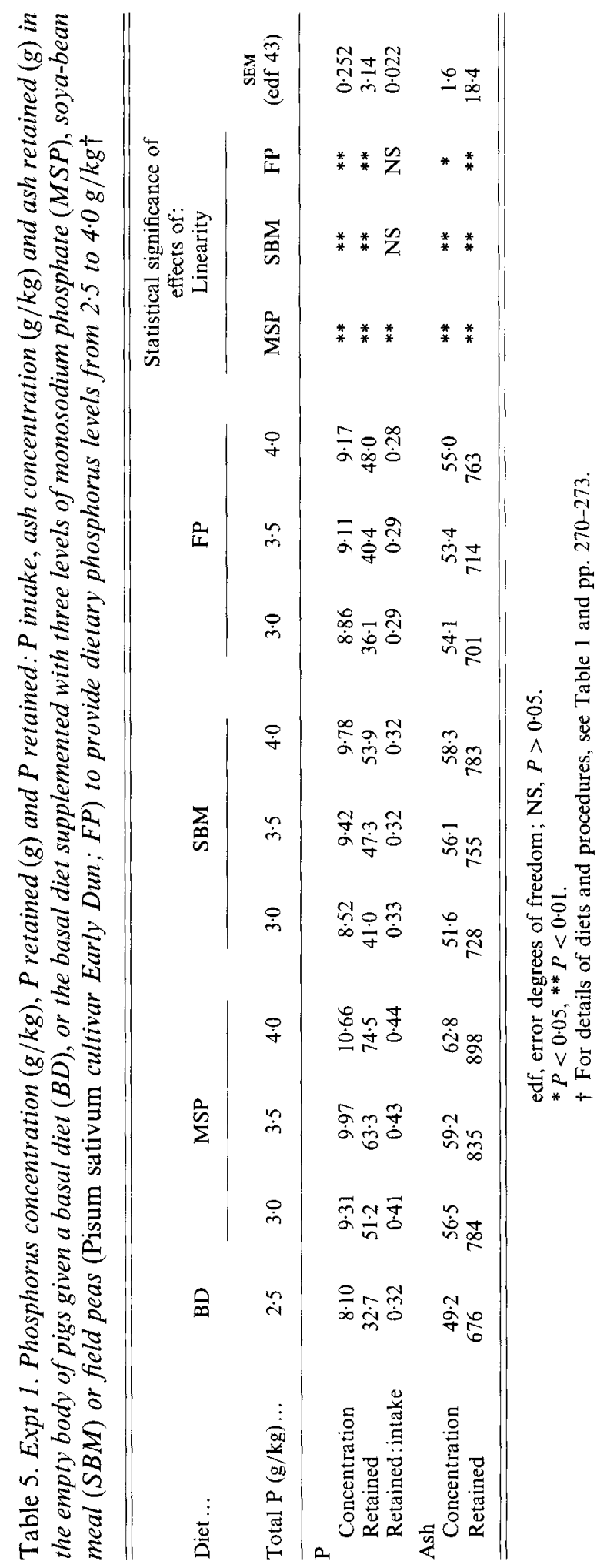


Table 6. Expt 1. Availability of phosphorus in soya-bean meal (SBM) and field peas (Pisum sativum cultivar Early Dun; FP) using slope responses of ash concentration and ash weight of various bones on $P$ concentrations in diets and $P$ intake as criteria for $P$ availability*

\begin{tabular}{|c|c|c|c|c|c|c|c|c|c|c|}
\hline \multirow[b]{3}{*}{ Criteria } & \multicolumn{5}{|c|}{ Based on $\mathrm{P}$ concentration in diets $\dagger^{\dagger}$} & \multicolumn{5}{|c|}{ Based on $\mathrm{P}$ intake $\dagger$} \\
\hline & \multicolumn{3}{|c|}{ Slope } & \multicolumn{2}{|c|}{$P$ availability } & \multicolumn{3}{|c|}{ Slope } & \multicolumn{2}{|c|}{$P$ availability } \\
\hline & MSP & SBM & FP & SBM & FP & MSP & SBM & FP & SBM & FP \\
\hline \multicolumn{11}{|l|}{ Ash concentration } \\
\hline Radius/ulna & $32 \cdot 9$ & $(1 \cdot 20)$ & $17 \cdot 40$ & $(0.04)$ & 0.53 & $25 \cdot 7$ & $(1 \cdot 2)$ & $12 \cdot 4$ & $(0 \cdot 05)$ & 0.48 \\
\hline Femur & $40 \cdot 07$ & $(5 \cdot 96)$ & 16.02 & $(0 \cdot 15)$ & $0 \cdot 40$ & $30 \cdot 9$ & $(4 \cdot 9)$ & $(10 \cdot 3)$ & $(0 \cdot 16)$ & $(0 \cdot 33)$ \\
\hline Metatarsal $_{4}$ & $22 \cdot 27$ & $(8 \cdot 20)$ & $15 \cdot 57$ & $(0 \cdot 37)$ & $0 \cdot 70$ & $18 \cdot 1$ & $(6 \cdot 6)$ & $(9 \cdot 8)$ & $(0.36)$ & $(0 \cdot 54)$ \\
\hline Average & & & & $(0 \cdot 19)$ & $0 \cdot 54$ & & & & $(0 \cdot 19)$ & $(0 \cdot 45)$ \\
\hline \multicolumn{11}{|l|}{ Ash weight } \\
\hline Radius/ulna & $32 \cdot 40$ & $(3 \cdot 80)$ & $9 \cdot 53$ & $(0 \cdot 12)$ & $0 \cdot 29$ & $2 \cdot 57$ & $(0 \cdot 35)$ & 0.92 & $(0 \cdot 14)$ & $0 \cdot 36$ \\
\hline Femur & $55 \cdot 40$ & $(10 \cdot 03)$ & $(10 \cdot 70)$ & $(0 \cdot 18)$ & $(0 \cdot 19)$ & $4 \cdot 34$ & $(0 \cdot 76)$ & $(1.08)$ & $(0 \cdot 18)$ & $(0 \cdot 25)$ \\
\hline Metatarsal $_{4}$ & 4.45 & $(1.01)$ & $(1.32)$ & $(0 \cdot 23)$ & $(0-30)$ & 0.35 & $(0.09)$ & $(0 \cdot 15)$ & $(0 \cdot 26)$ & $(0.43)$ \\
\hline Average & & & & $(0 \cdot 18)$ & $(0 \cdot 26)$ & & & & $(0 \cdot 19)$ & $(0 \cdot 35)$ \\
\hline
\end{tabular}

MSP, monosodium phosphate.

* For details of diets and procedures, see Table 1 and pp. 270-273.

$\uparrow$ Values in parentheses were not significantly linear.

with the increase in $\mathrm{P}$ level. Linear regressions of $\mathbf{P}$ content of the femur bones were not significantly different between the variable and constant $\mathrm{Ca}: \mathrm{P}$ ratio diets.

Bone ash responded quadratically $(P<0.01)$ to the increase of $\mathrm{P}$ levels in the variable $\mathrm{Ca}: \mathrm{P}$ ratio diets, up to a maximum of $4.4 \mathrm{~g} / \mathrm{kg}$ total $\mathrm{P}$.

Bone bending moment increased quadratically $(P<0 \cdot 01)$ with increasing dietary $P$ levels with both variable and constant $\mathrm{Ca}: \mathrm{P}$ ratio diets. In both cases the maximum bone bending moment resulted when the rats were given the diet containing $4.4 \mathrm{~g} / \mathrm{kg}$ total $\mathrm{P}$.

\section{Expt 3. Effect of calcium:phosphorus ratio in diets for rats}

Growth response. Feed intake of the rats increased linearly $(P<0.05 ; P<0.01)$ with the increase in $P$ levels regardless of $\mathrm{Ca}: \mathrm{P}$ ratio in the diets (Table 9).

Weight gain of the rats responded quadratically $(P<0.05, P<0.01)$ to the $\mathrm{P}$ levels regardless of $\mathrm{Ca}: \mathrm{P}$ ratio. The linear regressions of weight gain between variable and constant $\mathrm{Ca}: \mathrm{P}$ ratio were significantly $(P<0.01)$ different.

FCR decreased in a quadratic manner $(P<0.01)$ with increasing $\mathrm{P}$ level in the diets with variable but not with constant $\mathrm{Ca}: \mathrm{P}$ ratio.

Bone responses. Bone ash and bone-bending moment responded quadratically $(P<0.01)$ to the $\mathrm{P}$ levels in the diet regardless of the $\mathrm{Ca}: \mathrm{P}$ ratio (Table 9). The maximum bone ash was obtained when the rats were fed on diets containing $3.5 \mathrm{~g}$ total $\mathrm{P} / \mathrm{kg}$ with variable and $4.4 \mathrm{~g}$ total $\mathrm{P} / \mathrm{kg}$ with constant $\mathrm{Ca}: \mathrm{P}$ ratio diets. The maximum bone bending moment was obtained when the diets contained $3.5 \mathrm{~g}$ total $\mathrm{P} / \mathrm{kg}$ regardless of $\mathrm{Ca}: \mathrm{P}$ ratio in the diets. However, linear regressions between variable and constant $\mathrm{Ca}: \mathrm{P}$ ratios for both bone ash and bone bending moment were not significantly different. 


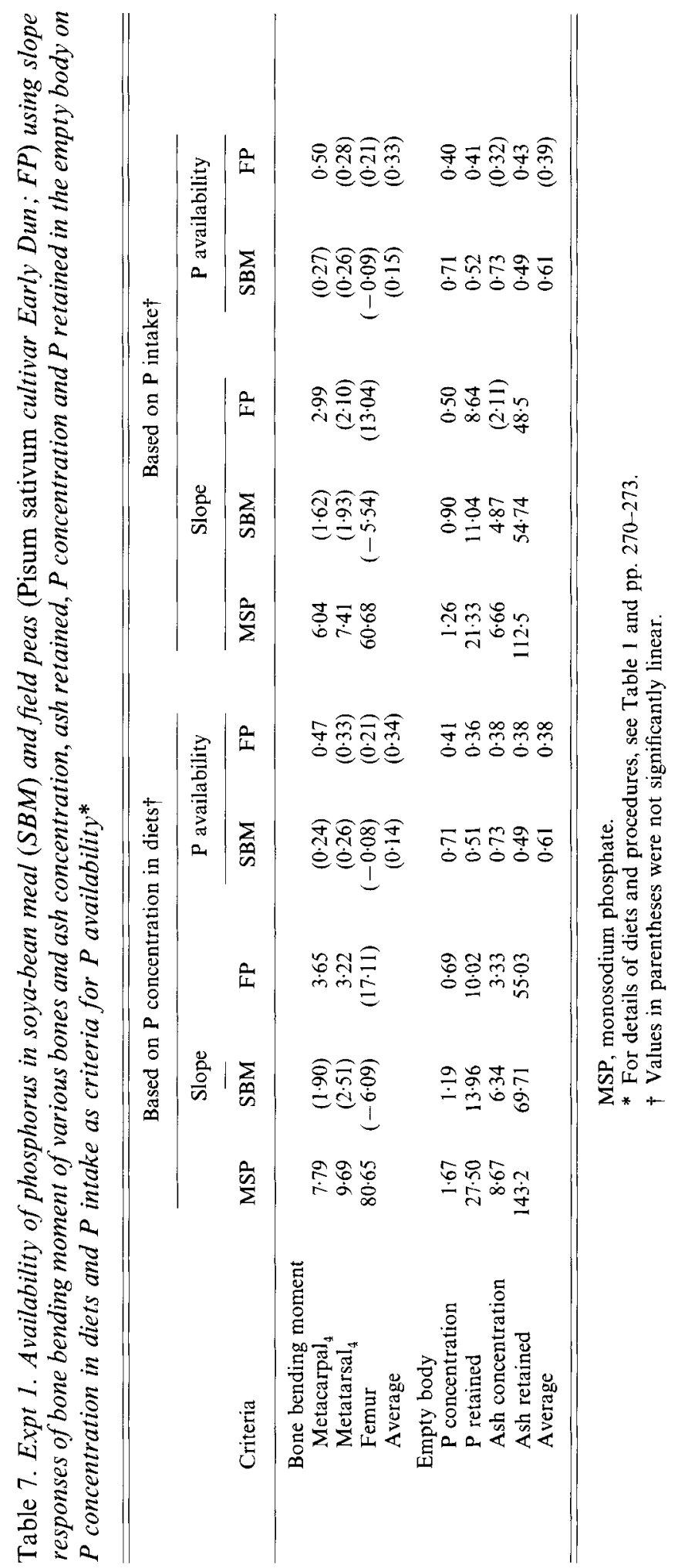


P AVAILABILITY FOR PIGS AND RATS

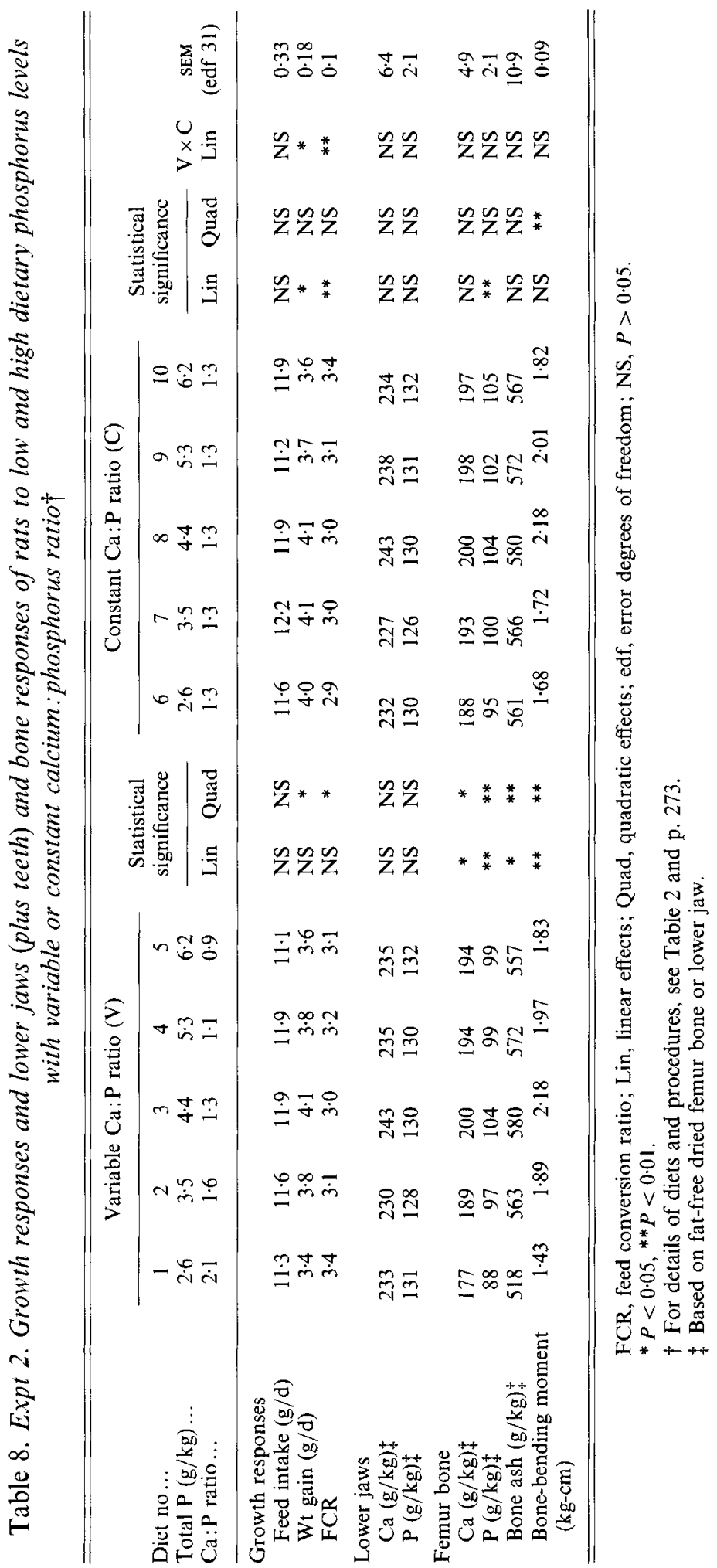




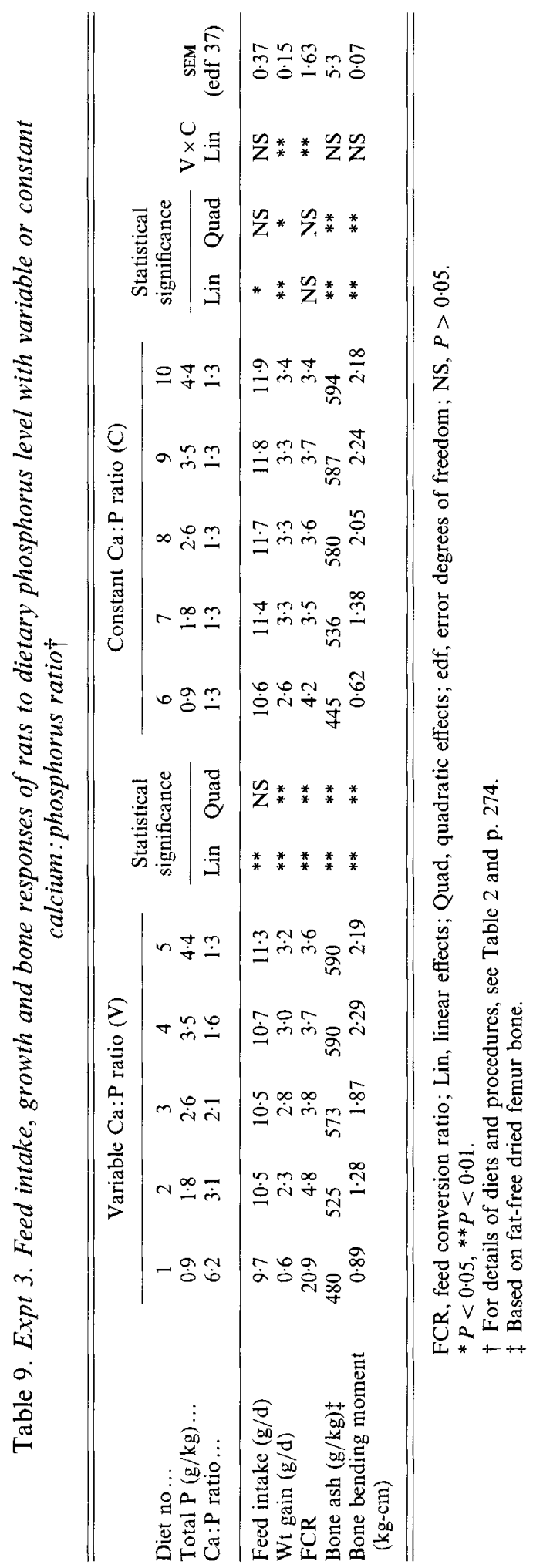


Table 10. Expt 4. Feed intake, growth responses and femur bone characteristics of rats given the basal diet $(B D)$, or the basal diet supplemented with three levels of monosodium phosphate (MSP) or soya-bean meal (SBM) to provide dietary phosphorus levels from 2.0 to $3.8 \mathrm{~g} / \mathrm{kg} \dagger$

\begin{tabular}{|c|c|c|c|c|c|c|c|c|c|c|}
\hline \multirow{3}{*}{$\begin{array}{l}\text { Diet ... } \\
\text { Total } P(g / k g) \ldots\end{array}$} & \multirow{3}{*}{$\begin{array}{l}\mathrm{BD} \\
2 \cdot 0\end{array}$} & \multirow{2}{*}{\multicolumn{3}{|c|}{ MSP }} & \multirow{2}{*}{\multicolumn{3}{|c|}{ SBM }} & \multicolumn{2}{|c|}{$\begin{array}{l}\text { Statistical } \\
\text { significance of } \\
\text { effects of: }\end{array}$} & \multirow{3}{*}{$\begin{array}{c}\text { SEM } \\
\text { (edf } 30)\end{array}$} \\
\hline & & & & & & & & & & \\
\hline & & $2 \cdot 6$ & $3 \cdot 2$ & 3.8 & $2 \cdot 6$ & $3 \cdot 2$ & $3 \cdot 8$ & Lin & Lin & \\
\hline Feed intake $(\mathrm{g} / \mathrm{d})$ & $12 \cdot 5$ & $12 \cdot 7$ & $12 \cdot 5$ & $12 \cdot 3$ & $13 \cdot 0$ & $13 \cdot 1$ & $13 \cdot 2$ & NS & NS & 0.32 \\
\hline Wt gain $(\mathrm{g} / \mathrm{d})$ & $3 \cdot 5$ & $3 \cdot 8$ & $4 \cdot 0$ & $3 \cdot 7$ & $4 \cdot 4$ & 42 & $4 \cdot 4$ & NS & NS & 0.28 \\
\hline FCR & $3 \cdot 6$ & $3 \cdot 4$ & $3 \cdot 2$ & $3 \cdot 4$ & $3 \cdot 1$ & $3 \cdot 3$ & $3 \cdot 2$ & NS & NS & $0 \cdot 18$ \\
\hline \multicolumn{11}{|l|}{ Femur bones } \\
\hline Fresh wt (mg) & 493 & 508 & 520 & 497 & 508 & 519 & 504 & NS & NS & 16 \\
\hline $\begin{array}{l}\text { Dry matter } \\
(\mathrm{g} / \mathrm{kg})\end{array}$ & 551 & 562 & 573 & 572 & 529 & 543 & 548 & NS & NS & 14 \\
\hline $\operatorname{Ash}(\mathrm{g} / \mathrm{kg}) \ddagger$ & 570 & 612 & 601 & 620 & 584 & 583 & 615 & * & NS & 15 \\
\hline
\end{tabular}

FCR, feed conversion ratio; Lin, linear effects; edf, error degrees of freedom; NS, $P>0.05$.

* $P<0.05$.

$\uparrow$ For details of diets and procedures, see Table 2 and p. 275

Based on fat-free dried femur bone.

Table 11. Expt 4. Bone bending moment $(\mathrm{kg}-\mathrm{cm})$ of rats given the basal diet $(B D)$ or the basal diet supplemented with three levels of monosodium phosphate (MSP) or soya-bean meal $(S B M)$ to provide dietary phosphorus levels from 2.0 to $3.8 \mathrm{~g} / \mathrm{kg} \dagger$

\begin{tabular}{|c|c|c|c|c|c|c|c|}
\hline \multirow[b]{2}{*}{$\begin{array}{l}\mathbf{P}(\mathrm{g} / \mathrm{kg}) \ldots \\
\text { Diets }\end{array}$} & \multirow[b]{2}{*}{$2 \cdot 0$} & \multirow[b]{2}{*}{$2 \cdot 6$} & \multirow[b]{2}{*}{$3 \cdot 2$} & \multirow[b]{2}{*}{$3 \cdot 8$} & \multicolumn{3}{|c|}{ Statistical significance } \\
\hline & & & & & Linear & Slope & Slope ratio \\
\hline $\mathrm{BD}$ & 1.55 & - & - & - & & & \\
\hline MSP & - & 1.91 & $2 \cdot 15$ & 2.06 & $* *$ & $0 \cdot 2964$ & \\
\hline SBM & - & 1.73 & 2.06 & 192 & $* *$ & 0.2405 & 0.81 \\
\hline
\end{tabular}

** $P<0.01$.

$\dagger$ For details of diets and procedures, see Table 2 and p. 275.

Expt 4. Availability of phosphorus in soya-bean meal for rats

Growth responses. Feed intake, weight gain and FCR were not affected by the level of $\mathrm{P}$ in the MSP or tests diets (Table 10).

Bone responses. Fresh weights and dry weights of the femur bone were not significantly influenced by the level of $P$ in the diet (Table 10). Bone ash responded linearly $(P<0.05)$ to the increase in $\mathrm{P}$ level in the MSP diets but was not affected by the test diets. However, bone bending moment of the femur bone was linearly $(P<0.01)$ increased by the increase in P level in the MSP and test diets (Table 11). The regression equations of MSP diets and test diets for bone bending moment responses $(Y ; \mathrm{kg}-\mathrm{cm}) v . \mathrm{P}$ concentrations in the diets $(X$; $\mathrm{g} / \mathrm{kg}$ ) were: $Y=1 \cdot 0594+0.2964 X$ and $Y=1 \cdot 1161+0.2405 X$ respectively. The availability of $\mathrm{P}$ in the soya-bean meal was $0.2405 / 0.2964=0.81$ (Table 11). For bone-bending responses $(Y ; \mathrm{kg}-\mathrm{cm})$ v. $\mathrm{P}$ intake $(X ; \mathrm{g} / \mathrm{d})$, the regression equations were: $Y=$ 
$0.9686+26.2153 X$ and $Y=1 \cdot 0844+19 \cdot 3394 X$ respectively while the estimate of the availability of $\mathrm{P}$ was $19 \cdot 3394 / 26 \cdot 2153=0 \cdot 74$.

\section{DISCUSSION}

\section{Availability of phosphorus in soya-bean meal and field peas for pigs}

The results indicate that the estimates of the availability of $\mathrm{P}$ in the test sources were entirely dependent on the criteria used to assess availability. When bone variables were used the availability of $P$ in soya-bean meal was low, approximately 0.17 (Tables 6 and 7). However, when availability was based on ash or $\mathrm{P}$ concentration or ash or $\mathrm{P}$ retained in the empty body the mean estimate of availability was much higher $(0 \cdot 61)$. However, these differences were not consistent with the field peas where the estimates of availability based on empty body weight $(0.38)$ were similar or slightly lower if the comparison was restricted to the estimates where the responses of bone variables were linear $(0.43)$.

The reason for the findings described previously may have been that the availability of $P$ was generally underestimated with the non-linear responses. For example, with pigs receiving the field-pea diet the estimate was 0.33 when non-linear (bone bending moment of metatarsal) and 0.47 when linear (bone bending moment of metacarpal) responses were taken as criteria for the availability of $P$.

This is also supported by the fact that the mean estimate of the availability of $P$ in the soya-bean meal $(0.17)$ based on non-linear bone responses is much lower than the estimated $P$ retention ( 0.33$)$ (Table 12). This is very unlikely as the availability of $\mathrm{P}$ obtained by the slope-ratio assay is a relative estimate to the MSP which is given a value of 1.0 . In fact, it was found that the mean P retention of the MSP was only 0.74 (Table 12). Thus, the estimate of availability of $P$ is expected to be greater than $P$ retention.

All the estimates for availability of $P$ in soya-bean meal that were based on bone variables were strictly invalid in the sense that the responses were non-linear. However, the results were calculated because they do indicate that the responses were very low. The lack of linearity may well have been due to the low increases in these variables. This is highlighted by the large responses to MSP, which were linear in all cases, supporting the contention that the lack of linearity may have been due to the very low increments of available $P$ with the soya-bean-meal or field-pea diets.

There was little difference between the estimates for availability based on $\mathrm{P}$ intake compared with concentration of $\mathbf{P}$ in the diets. This is not surprising as the pigs were restrictively fed at a constant feeding rate based on live weight (three times maintenance). It is only where pigs are fed $a d l i b$. and differences in feed intake develop that differences in availability estimates may occur. However, if differences in dietary intake occur then there will be differences in the amount of $\mathrm{P}$ consumed from the basal diet and there is a need to correct for the estimated availability of $\mathrm{P}$ in the basal diet. Thus, conducting the slope-ratio assay on a restricted feeding basis and assessing the response $v$. concentration in the diet avoids this problem.

In general, there were no consistent trends in availability estimates based on the concentration or weight of ash in the bones relative to estimating bone bending moment. This is probably because most of the bone responses to the dietary $\mathbf{P}$ concentration were non-linear. Nevertheless, Cromwell et al. (1972) also reported no relationship between ash concentration in the bone and bone bending moment.

The depressing effects of field peas on growth performances were unusual in that a similar effect did not occur with the soya-bean meal. Thus, the depressing effects with field peas are unlikely to be related to excess protein in the diet. Field peas contain no known anti-nutritional factors other than trypsin inhibitors $(1.1 \mathrm{mg} / \mathrm{g}$; Saini \& Batterham, 
Table 12. Expt 1. Total phosphorus intake $(g)$, $P$ retained $(g)$ and calculated $P$ retained: $P$ intake $(\mathrm{g} / \mathrm{g})$ of pigs given the monosodium phosphate (MSP), soya-bean meal (SBM) and field peas (Pisum sativum cultivar Early Dun; FP) diets assuming that $P$ retained: $P$ intake in the basal diet $(B D)$ remains constant at 0.32 in all diets ${ }^{*}$

\begin{tabular}{|c|c|c|c|c|c|c|c|c|c|}
\hline \multirow{2}{*}{$\begin{array}{l}\text { Diet ... } \\
\text { Total P }(\mathrm{g} / \mathrm{kg}) \ldots\end{array}$} & \multicolumn{3}{|c|}{ MSP } & \multicolumn{3}{|c|}{ SBM } & \multicolumn{3}{|c|}{ FP } \\
\hline & $3 \cdot 0$ & $3 \cdot 5$ & $4 \cdot 0$ & 3.0 & $3 \cdot 5$ & $4 \cdot 0$ & $3 \cdot 0$ & $3 \cdot 5$ & $4 \cdot 0$ \\
\hline \multicolumn{10}{|l|}{$P$ intake } \\
\hline Total & $124 \cdot 1$ & $146 \cdot 5$ & $169 \cdot 8$ & $126 \cdot 1$ & $146 \cdot 3$ & $169 \cdot 8$ & $121 \cdot 4$ & 139.9 & $169 \cdot 0$ \\
\hline $\begin{array}{l}\text { Originated from } \\
\text { BD }\end{array}$ & 103.4 & $104 \cdot 7$ & $106 \cdot 1$ & $105 \cdot 1$ & $104 \cdot 5$ & $106 \cdot 1$ & $101 \cdot 2$ & 99.9 & $105 \cdot 6$ \\
\hline $\begin{array}{l}\text { Originated from } \\
P \text { source }\end{array}$ & $20 \cdot 7$ & $41 \cdot 8$ & $63 \cdot 7$ & $21 \cdot 0$ & $41 \cdot 8$ & $63 \cdot 7$ & $20 \cdot 2$ & $40 \cdot 0$ & $63 \cdot 4$ \\
\hline \multicolumn{10}{|l|}{$P$ retained } \\
\hline Total & $51 \cdot 2$ & $63 \cdot 3$ & $74 \cdot 5$ & $41 \cdot 0$ & $47 \cdot 3$ & $53 \cdot 9$ & $36 \cdot 1$ & $40 \cdot 4$ & $48 \cdot 0$ \\
\hline $\begin{array}{l}\text { Originated from } \\
\text { BD }\end{array}$ & $33 \cdot 1$ & $33 \cdot 5$ & $34 \cdot 0$ & $33 \cdot 6$ & $33 \cdot 4$ & $34 \cdot 0$ & $32 \cdot 4$ & $32 \cdot 0$ & $33 \cdot 8$ \\
\hline $\begin{array}{l}\text { Originated from } \\
\text { the } P \text { source }\end{array}$ & $18 \cdot 1$ & $29 \cdot 8$ & $40 \cdot 5$ & $7 \cdot 4$ & $13 \cdot 9$ & $19 \cdot 9$ & $3 \cdot 7$ & $8 \cdot 4$ & $14 \cdot 2$ \\
\hline $\begin{array}{l}\text { Calculated } \mathbf{P} \\
\text { retained: } \mathbf{P} \\
\text { intake }\end{array}$ & 0.874 & 0.713 & 0.636 & $0 \cdot 352$ & 0.333 & $0 \cdot 312$ & 0.183 & $0 \cdot 208$ & 0.224 \\
\hline $\begin{array}{l}\text { Mean calculated } \\
P \text { retained: } P \\
\text { intake }\end{array}$ & & $0 \cdot 74$ & & & $0 \cdot 33$ & & & $0 \cdot 21$ & \\
\hline
\end{tabular}

* For details of diets and procedures, see Table 1 and pp. 270-273.

1990). However, the total level of trypsin inhibitor contributed by the field peas was well below that found to be tolerated by the grower pig $(4.7 \mathrm{mg} / \mathrm{g}$; Batterham et al. 1990).

The depressing effects of field peas on the growth responses also highlight one of the disadvantages of the slope-ratio assay, that of concentration of nutrients. It is necessary for the basal diet to be adequate in protein so that changes in dietary protein do not affect the responses. However, when assessing the availability of $P$ in protein concentrates the total inclusion levels of protein from the basal and test sources are high, much higher than normally fed. This combination of excess protein could be expected to depress growth responses in many cases.

Overall, the results indicate large differences in the estimates of the availability of $\mathrm{P}$ in soya-bean meal and field peas depending on the criteria used to assess availability. For soya-bean meal the estimates were considerably lower using bone variables $(0 \cdot 17)$ compared with estimates based on empty body concentrations or retentions $(0.61)$. With field peas, however, there was no difference $(0 \cdot 38)$. These estimates also bear no relationship to the estimated retention of $P$ from the soya-bean meal $(0.33)$ and field peas $(0.21)$. There is a need for further work to determine which are the most realistic estimates of availability in these meals.

Availability of phosphorus in soya-bean meal for rats

These studies indicate that bone bending moment is a suitable response criterion for assessing the availability of $\mathbf{P}$ using a slope-ratio assay with growing rats. Bone bending moment responded in a linear manner within a specified $\mathbf{P}$ range and was unaffected by the 
$\mathrm{Ca}: \mathrm{P}$ ratio in the diets. This latter attribute is necessary as it is not possible to provide an optimum $\mathrm{Ca}: P$ ratio in the diets as the availability of $\mathbf{P}$ is unknown in the test material. Using the assay procedure, the slope-ratio between test diet and MSP diet was 0.81 and 0.74 for the regressions $v$. P concentration and $\mathrm{P}$ intake respectively. This indicates that the availability of $P$ in soya-bean meal for rats is 0.81 assuming that $P$ availability in MSP is 1.0. Other variables such as fresh weight or dry matter and bone ash of the femur bones were not suitable as response criteria as they did not respond linearly to the change of dietary P level.

In addition to a linear response to increasing concentration of total $\mathrm{P}$, a suitable criterion must be unaffected by the $\mathrm{Ca}: \mathrm{P}$ ratio of the diets. In this regard, the ash and $\mathrm{P}$ contents and the bone bending moment of the femur bone in Expts 2 and 3 appeared to be the most suitable criteria. However, even with the ash content and bone bending moment of the femur bones there was evidence of curvilinearity at the highest levels of dietary $P$ tested in Expts 2 and 3 . Thus, a suitable range of dietary $P$ concentrations for the slope-ratio assay to ensure linearity in response would be from 0.9 to $3.5 \mathrm{~g} / \mathrm{kg}$. This corresponded to $\mathrm{Ca}: \mathrm{P}$ ratios of between 1.3 and 6.2. However, the lowest level of dietary $P$ in Expt 3 resulted in depressed weight gain and greatly inferior FCR. For this reason, $0.9 \mathrm{~g} / \mathrm{kg}$ total $\mathrm{P}$ may be too low a level to use in slope-ratio assays and levels of $2 \mathrm{~g} / \mathrm{kg}$ may be more suitable.

The results also show that feed intake, growth rate and FCR were unsuitable as criteria of response as they were insensitive to dietary $P$ level, or else were sensitive to changes in the Ca: $\mathrm{P}$ ratio. These results are in agreement with the work of Moore et al. (1984), who reported that both weight gain and FCR responded quadratically while the development of femur bone responded linearly when rats were given diets containing $1.5-4.5 \mathrm{~g} / \mathrm{kg}$.

The quadratic responses in weight gain in Expt 3 indicated that the rat's requirement for total $\mathrm{P}$ was $1.8 \mathrm{~g} / \mathrm{kg}$ with a $\mathrm{Ca}: \mathrm{P}$ ratio of 1.3 . This supports the work of Henry et al. (1979) who indicated that $2 \mathrm{~g}$ total $\mathrm{P} / \mathrm{kg}$ dry matter (DM) was sufficient to support normal growth but insufficient to ensure adequate bone mineralization. They also reported that a dietary level of $1.2 \mathrm{~g}$ total $\mathrm{P} / \mathrm{kg} \mathrm{DM}$ reduced feed intake and weight gain of rats and was associated with a decrease in $\mathrm{N}$ and energy retention in the body.

The results also indicate that increasing $\mathrm{Ca}: \mathrm{P}$ ratio is detrimental to growth and has no effect on bone ash or bone bending moment of the femur bones. When the $\mathrm{Ca}: \mathrm{P}$ ratio was 1.6 or higher the growth rate of rats was depressed, but not when the value was 1.3 . This indicates that diets with excess $\mathrm{Ca}$, such as at high $\mathrm{Ca}: \mathrm{P}$ ratios with low $\mathrm{P}$, were responsible for the depression in weight gain rather than because of insufficient $P$. The National Research Council (1972) reported that a wide $\mathrm{Ca}: \mathrm{P}$ ratio in a diet retarded growth and reduced feed intake of rats. Goto \& Sugai (1974) also reported that both weight gain and $\mathrm{N}$ retention were reduced when adult rats were fed excess $\mathrm{Ca}(20 \mathrm{~g} / \mathrm{kg})$ in a normal $\mathrm{P}$ diet $(5.0 \mathrm{~g} / \mathrm{kg})$.

It was apparent that the $\mathrm{Ca}$ and $\mathrm{P}$ contents in the lower jaws of the rats were insensitive to changes in dietary $\mathrm{P}$ concentration or $\mathrm{Ca}: \mathrm{P}$ ratio and, therefore, not suitable as criteria of response. This is in agreement with Oser (1965) who found that mineral concentrations of teeth were unaffected by dietary $P$ levels while the values in bones were reduced.

The requirement for total $\mathrm{P}$ to maximize the bone bending moment in Expt 2 was higher than in Expt 3. This could be due to a difference in available $P$ content between the diets at the same total $P$, as the result of different inclusion levels of soya-bean meal in both experiments. It was calculated that the dietary available P in Expt 2 was about $35 \%$ lower than the corresponding value in Expt 3 . This may also apply to the femur ash response where its value was lower in Expt 2 than in Expt 3 at the same total P level. This suggests that in assessing $P$ requirements for rats the amount of $P$ supplied by each feed ingredient, particularly of plant origin, should be considered. Different proportions of plant $\mathrm{P}$ in diets 
may result in different optimum $P$ levels being recommended, particularly when the $P$ requirement is expressed as total $\mathbf{P}$ in the diets.

Overall, the results indicate that the estimate of the availability of $P$ in soya-bean meal for rats $(0.81)$ is approximately two to three times higher than the value for pigs $(0.25-0.38)$ as reported by the National Research Council (1988) and four times higher than as determined in Expt $1(0 \cdot 17)$ with the same meal. This suggests that rats are more capable of utilizing phytate-P than pigs. This may be due to differences in phytase (EC 3.1.3.26) activity in the digestive tracts of rats and pigs. Cosgrove (1980) and Davies \& Flett (1978) reported that phytase is present and hydrolyses phytate-P in the small intestines of rats. Approximately $71 \%$ of phytate-P in a soya-bean meal-maize-based diet was hydrolysed by growing rats (Nelson \& Kirby, 1979). On the other hand, Pointillart et al. (1987) found negligible phytase activity in the small intestines of pigs. Calvert et al. (1978) also reported that pigs only digested a small amount of $P$ in barley and maize (16.5-41.3 and 8.3\% respectively). As a consequence it is unlikely that the rat can be used to predict the availability of $\mathbf{P}$ in diets for pigs.

The authors are grateful to Dr B. K. Milthorpe (Centre for Biomedical Engineering, University of New South Wales, Sydney) for assistance with the determination of the bone bending moment and Ms E. White for statistical analyses. Financial support from the Australian International Development Assistance Bureau and the Pig Research and Development Corporation is gratefully acknowledged.

\section{REFERENCES}

Agricultural Research Council (1981). The Nutrient Requirements of Pigs. Slough: Commonwealth Agricultura Bureaux.

Batterham, E. S., Andersen, L. M., Saini, H. S. \& Baigent, D. R. (1993). Tolerance of growing pigs to trypsin and chymotrypsin inhibitors in chickpeas (Cicer arietinum) and pigeon peas (Cajanus cajan). Journal of the Science of Food and Agriculture 61, 211-216.

Calvert, C. C., Besecker, R. J., Plumlec, M. P., Cline, T. R. \& Forsyth, D. M. (1978). Apparent digestibility of P in barley and corn for growing swine. Journal of Animal Science 47, 420-426.

Cosgrove, D. J. (1980). Inositol Phosphates. Their Chemistry, Biochemistry and Physiology. Amsterdam: Elsevier Scientific Publishing Company.

Crenshaw, T. D., Peo, E. R. Jr, Lewis, A. J. \& Moser, B. D. (1981). Bone strength as a trait for assessing mineralisation in swine: a critical review of techniques involved. Journal of Animal Science 53, 827-835.

Cromwell, G. L. (1980). Biological availability of phosphorus for pigs. Feedstuffs 52, 3842.

Cromwell, G. L. (1989). Requirements, biological availability of calcium, phosphorus for swine evaluated. Feedstuffs 60, 16-25.

Cromwell, G. L., Hays, V. W., Scherer, C. W. \& Overfield, J. R. (1972). Effects of dietary calcium and phosphorus on performance and carcass, metacarpal and turbinate characteristics of swine. Journal of Animal Science 34, $746-751$.

Davies, N. T. \& Flett, A. A. (1978). The similarity between alkaline phosphatase (EC 3.1.3.1) and phytase $(E C 3.1 .3 .8)$ activities in rat intestine and their importance in phytate-induced zinc deficiency. British Journal of Nutrition 39, 307-316.

Davies, R. L. (1984). Field peas (Pisum sativum) as a feed for growing and finishing pigs. 1. Nutrient levels in commercial crops. Australian Journal of Experimental Agriculture and Animal Husbandry 24, 350-353.

Goto, S. \& Sugai, T. (1974). Effect of excess calcium intake on absorption of nitrogen, fat, phosphorus and calcium in adult rats. Nutrition Reports International 11, 49-54.

Henry, Y., Gueguen, L. \& Rerat, A. (1979). Influence of the level of dietary phosphorus on the voluntary intake of energy and metabolic utilization of nutrients in the growing rat. British Journal of Nutrition 42, $127-137$.

John, M. K. (1970). Colorimetric determination of phosphorus in soil and plant materials with ascorbic acid. Soil Science 109, 214-220.

Johnson, C. M. \& Ulrich, A. (1959). Analytical methods for use in plant analysis. California Agricultural Experiment Station Bulletin no. 766, pp. 25-78. California: University of California.

Ketaren, P. P., Batterham, E. S., White, E., Farrell, D. J. \& Milthorpe, B. K. (1993). Phosphorus studies in pigs. 1. Available phosphorus requirements of grower/finisher pigs. British Journal of Nutrition 70, 249-268.

Koch, M. E. \& Mahan, D. C. (1985). Biological characteristics for assessing low phosphorus intake in growing swine. Journal of Animal Science 60, 699-708. 
Moore, R. J., Reeves, P. G. \& Veum, T. L. (1984). Influence of dietary phosphorus and sulphaguanidine levels on $P$ utilization in rats. British Journal of Nutrition 51, 453-465.

National Research Council (1972). Nutrient Requirements of Laboratory Animals. Washington, DC: National Academy of Sciences.

National Research Council (1988). Nutrient Requirements of Swine. Washington, DC: National Academy Press.

Nelson, T. S. \& Kirby, L. K. (1979). Effect of age and diet composition on the hydrolysis of phytate phosphorus by rats. Nutrition Reports International 20, 729-734.

Oser, B. L. (1965). Hawk's Physiological Chemistry, 14th ed. New York: McGraw-Hill Inc.

Pointillart, A., Fourdin, A. \& Fontaine, N. (1987). Importance of cereal phytase activity for phytate phosphorus utilisation by growing pigs fed diets containing triticale or corn. Journal of Nutrition 117, 907-913.

Saini, H. S. \& Batterham, E. S. (1990). Distribution of trypsin and chymotrypsin inhibitors in feeds and tolerances of growing pigs to these inhibitors. In Pig Industry Seminar, pp. 18-22 [G. A. Taylor, editor]. Wollongbar: Media Unit, North Coast Agricultural Institute.

Standing Committee on Agriculture (1987). Feeding Standards for Australian Livestock. Pigs. East Melbourne: CSIRO Press. 